\section{University reforms fail to quell fears of 'inbreeding'}

Xavier Bosch, Barcelona

Responding to mounting evidence that Spain's university system is one of the most inward-looking in the world, the Spanish government has announced sweeping reforms of the system.

But as public comment closed last week on the reform plan, many researchers were complaining that it does not go far enough.

The new measures include arrangements for evaluating and selecting candidates for junior and full professorships; a programme to lure young Spanish scientists back into the country (see Nature 410, 1014; 2001); and a new agency to assess university research.

Critics have focused on how candidates will be vetted for faculty positions. The plan would introduce more open, meritbased competition to the early part of the recruitment process, but still leaves the final appointment step in the hands of a panel chosen by the university itself.

Ismael Crespo-Martínez, director of universities at the education ministry, says that the new system will put an end to 'inbreeding' in Spanish universities and will boost the mobility of researchers.

But almost 500 staff from 60 universities have sent an open letter to the education minister, Pilar del Castillo, stating that the "anti-inbreeding measures of the new law are no longer useful if the university panel is not made up of outside professors with no scientific links with the applicant".

One recent survey suggested that the existing system, which gives universities complete autonomy in hiring, leaves Spanish universities ten times more likely to appoint internal candidates to faculty positions than those elsewhere (see Nature 410, 14; 2001)

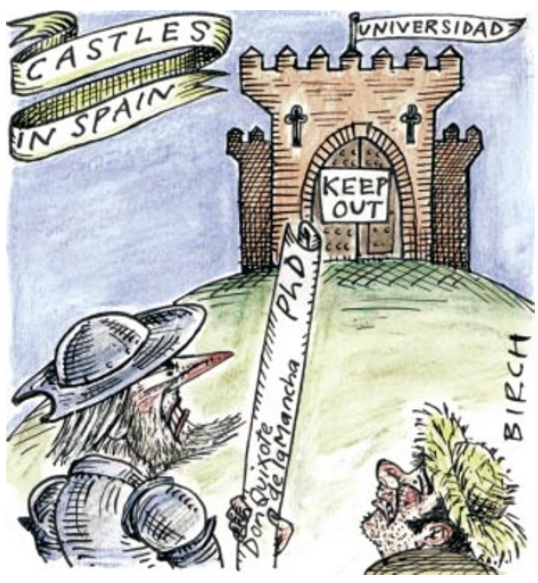

\title{
Utopian dream in tatters as Starlab crashes to Earth
}

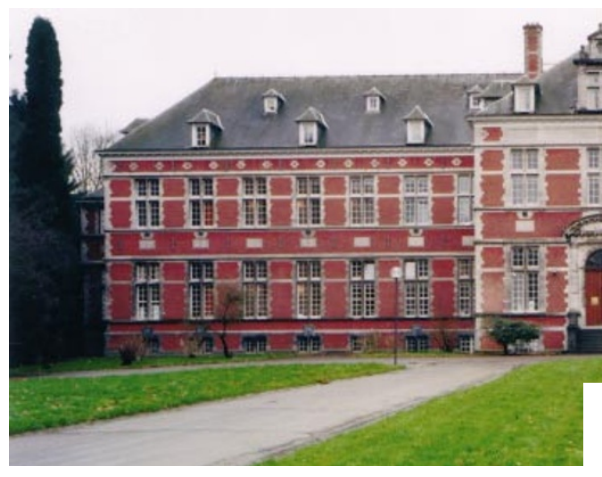

Jim Giles, Brussels

An ambitious attempt to create a utopian environment for advanced, interdisciplinary research has come to grief. Starlab, a privately funded centre in Brussels that encouraged its researchers to generate innovative ideas, free from the pressure to publish or to develop products, went bust last month. Its 100 staff are now looking for new jobs.

Walter de Brouwer, a former mathematician, established Starlab in 1996 with US\$5 million that he made in computer publishing. Loosely modelled on the Massachusetts Institute of Technology's Media Lab, Starlab started with a core of computer scientists and experts in multimedia technology. As technology stocks soared, de Brouwer raised money from like-minded investors, and expanded Starlab to hire physicists interested in quantum computing and nanotechnology. Biology labs were added in 1999.

Many research centres are trying to forge links between these disciplines. But Starlab differed in its rejection of traditional corporate or academic structures and quality assessment, and its anarchic approach to cross-disciplinary collaboration. De Brouwer's philosophy was that Starlab was created to generate ideas, not products, as reflected in one of the centre's slogans: "We do not make things that work." He describes peer review as "the calibration of mediocrity performed by bearded men".

Starlab provided a haven for scientists with unconventional ideas. Hugo de Garis, for example, was exploring a new approach to artificial intelligence, dubbed 'brain building', in which he tried to simulate animal cognitive abilities by wiring together reconfigurable computer chips. Central to Starlab's ethos was its weekly brainstorming session, known as the 'great ideas club', in which scientists from diverse backgrounds would discuss one another's work and dream up potential projects.

When Nature visited Starlab in May, the enthusiasm of many of its scientists was obvious. "People are much less sceptical at

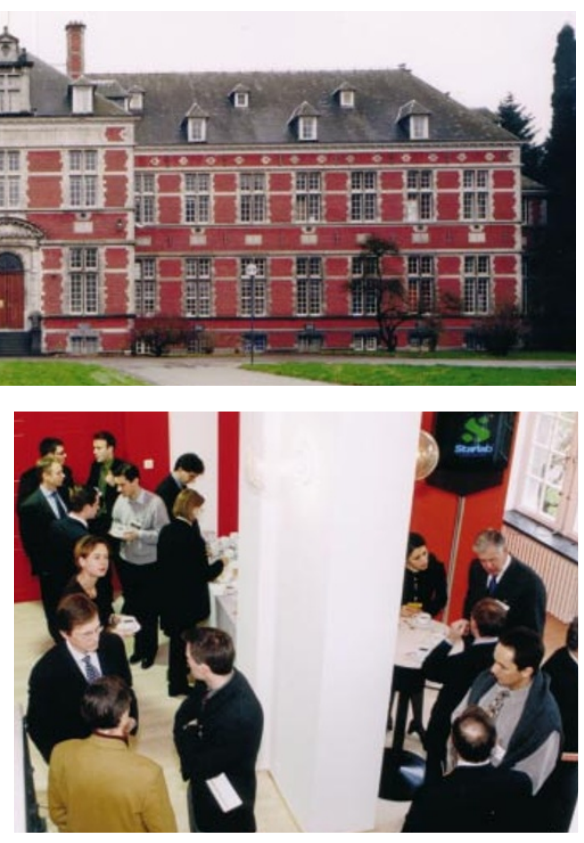

Paradise lost: Starlab's elegant Belgian base will no longer echo to brainstorming sessions.

Starlab,” said stem-cell biologist Isabelle Bouhon, who was collaborating with mathematician Keith Still to study the 'emergent properties' of developing cells and tissues.

But by then, the writing was on the wall. Too few of Starlab's 'great ideas' were attracting commercial interest, and investors had declined to buy bonds in the centre. By the end of May, Starlab was unable to pay its staff. And on 11 June, when a group of existing investors withdrew their support, de Brouwer was forced to call in receivers.

Starlab's remaining assets, including its elegant, former embassy building, may have to be sold to cover debts of some US $\$ 3.5$ million. Some former staff have been in talks with the Brussels regional government in the hope of resurrecting the centre in a more conventional commercial guise. But for now, things look bleak. "All the scientists have had to be fired," says de Brouwer. "I am trying to ensure that they get five months' salary."

The leaders of a second Starlab, at the Fabra Observatory on the outskirts of Barcelona, hope to survive the demise of its parent by raising further investment on their own. The Spanish lab currently employs 10 researchers and had plans to expand.

As former employees in Brussels ponder their futures, some have concluded that Starlab's experiment in research organization was a step too far. De Garis complains that he was unable to build a research group. "What I really need now is security," he says.

it htp://www.starlab.org 